\title{
PERSEPSI SISWA TERHADAP CARD SORT SEBAGAI MEDIA PEMBELAJARAN HIRAGANA
}

\section{Monica Sepwanda ${ }^{1}$, Damai Yani ${ }^{2}$}

Program Studi Pendidikan Bahasa Jepang, Bahasa dan Sastra Inggris, Fakultas Bahasa dan Seni, Universitas Negeri Padang, Balingka, 26160

Program Studi Pendidikan Bahasa Jepang, Bahasa dan Sastra Inggris, Fakultas Bahasa dan Seni, Universitas Negeri Padang, Jondul 2 Blok b 22 Asrama Haji, 25171 Email Penulis : monicasepwanda@gmail.com

\section{Sejarah Artikel \\ Submit : :2020-10-17 \\ Diterima : 2021-02-19 \\ Diterbitkan : 2021-06-09}

\section{Kata Kunci:}

Hiragana, card sort, persepsi.

\begin{abstract}
Letters or in Japanese are known as moji is one of the characteristics of Japanese. There are three types of letters in Japanese namely kanji, kana and romaji. One part of kana's letter is hiragana. When learners learning about hiragana still often encounter problems as similar letter form and number of hiragana. In reference to the results of the questionnaire who had the researchers spread beforehand at the learner while carrying out field work practices at SMAN 3 Bukittinggi showed that learners needed media to facilitate learning to remember and understand hiragana. To overcomethe difficulty in understanding the hiragana, researchers have tried to use one of the types of visual media, namely card sort. The goal of this study is to expose the perceptions of student against card sort as a hiragana learning media. The research method of this study is descriptive quantitative. While the sampling technique uses in this study was purposive sampling. The respondents in this study is the students of class $X$ BAHASA which amount of 35 peoples. This research instrument is a questionnaire. The type of questionnaire used is closed type questionnaire. Based on the results of the questionnaire analysis, it is kwon that the student's perception of the card sort as a "good" hiragana learning media with a percentage of $83,22 \%$. Refers to these results it can be seen that the media card sort can be used to facilitate the side to remember and understand hiragana.
\end{abstract}

\footnotetext{
${ }^{1}$ Mahasiswa Prodi Pendidikan Bahasa Jepang FBS UNP lulus pada tanggal 02-11-2020

${ }^{2}$ Dosen Prodi Pendidikan Bahasa Jepang FBS UNP
} 


\section{PENDAHULUAN}

Bahasa adalah unsur penting dalam sebuah sistem komunikasi. Senada dengan yang diungkapkan oleh Sutedi (2011) penggunaan bahasa sebagai alat komunikasi bertujuan untuk menyampaikan ide, pikiran, hasrat kepada orang lain, hal ini menunjukkan bahwasannya bahasa bagian terpenting dalam berkomunikasi. Sementara itu Parera (dalam Welhelmina, 2017) menyatakan bahwa, bahasa yang dipelajari oleh seorang peserta didik selain bahasa ibu disebut dengan bahasa asing. Salah satu bahasa asing yang dipelajari oleh pembelajar pada tingkat SMA adalah bahasa Jepang. Bahasa Jepang memiliki karakter yang berbeda dengan bahasa Indonesia.

Lebih lanjut Kindaiichi (dalam Renariah, 2002) mengklasifikasikan karakteristik bahasa Jepang dalam 5 kelompok besar yaitu hatsuon (ucapan), moji (huruf), goi (kosakata), bunpo (tata bahasa), dan hyogen (ekspresi). Dari lima karakteristik tersebut peneliti tertarik untuk membahas mengenai moji (huruf). Dalam belajar bahasa Jepang, moji (huruf) merupakan hal dasar yang penting dikuasai oleh pembelajar bahasa Jepang. Hal ini dapat dilihat dengan adanya pembelajaran huruf dasar, salah satunya yaitu hiragana.

Dalam mempelajari hiragana terdapat beberapa masalah yang kerap dialami oleh pembelajar bahasa Jepang. Sutedi (2018) menyebutkan dalam mempelajari hiragana ada beberapa masalah yang biasa dihadapi oleh pembelajar tingkat pemula yaitu, ketika mempelajari hiragana pembelajar sering terkecoh dengan bentuk hiragana yang hampir mirip, seperti あ(a) dan お (o), わ (wa), ね (ne) dan れ (re), ぬ (nu), め (me) dan (no). Jumlah hiragana yang banyak juga seringkali menjadi hambatan pembelajar dalam penguasaan hiragana, mengingat terdapat 46 huruf dasar hiragana, 32 huruf hiragana yang memakai dakuten $\left.\Gamma^{*}\right\rfloor, 8$ huruf hiragana yang memakai handakuten $\left.\Gamma^{\circ}\right\rfloor$, dan sebanyak 21 konsonan ganda yang memakai ya/yu/yo kecil 「きや(kya)、きゆ(kyu)、きょ(kyo)」, jadi huruf hiragana yang harus dikuasai oleh pembelajar tingkat pemula menjadi 107 huruf. Selain itu menurut (Haq, 2019), metode pengajaran huruf hiragana yang diajar oleh guru masih terfokus kepada buku teks sehingga diperlukan alternatif media lain dalam pengajaran.

Berdasarkan hasil angket yang telah peneliti sebarkan sebelumnya pada pembelajar ketika melaksanakan praktik lapangan kependidikan (PLK) di SMAN 3 Bukittinggi, hambatan yang disebutkan di atas juga terjadi pada saat belajar mengenai hiragana. Kesimpulan dari hasil angket tersebut menyebutkan bahwasannya pembelajar memerlukan media untuk mempermudah dalam mengingat dan memahami hiragana.

Media merupakan segala hal yang dapat menyampaikan informasi dari pengirim kepada penerimanya yang menyebabkan timbulnya stimulus pikiran, perasaan, minat serta perhatian pembelajar sehingga terjadinya proses belajar (Sadiman dkk, 2014). Dalam hal ini peneliti telah menggunakan media card sort yang merupakan salah satu media visual untuk mengatasi kesulitan dalam memahami pembelajaran hiragana. Menurut Zaini (dalam Nikmah, 2017) card sort merupakan suatu kegiatan yang dapat digunakan untuk mengajarkan konsep, fakta, klasifikasi, karakteristik tentang sesuatu objek atau meriview sebuah informasi yang dilakukan secara kolaboratif. 
Selama menggunakan media card sort pembelajar lebih termotivasi untuk memahami pembelajaran hiragana. Selain itu, pembelajaran mejadi lebih menyenangkan dan pembelajar dapat terlibat secara aktif selama pembelajaran berlangsung. Sesuai dengan pernyataan Yani (2017) yang menyatakan, kegunaan media untuk meningkatkan gairah belajar, meningkatkan kemampuan siswa untuk belajar secara mandiri dan terjadinya interaksi langsung antar pembelajar dengan lingkungan dalam pembelajaran. Akan tetapi, media card sort ini juga memiliki kelemahan yaitu karena media card sort ini terbuat dari kertas menyebabkan kartu ini mudah rusak. Oleh karena itu, sebaiknya gunakanlah kartu yang terbuat dari bahan yang tahan lama atau keras, agar lebih meminimalisir cepat terjadinya kerusakan terhadap kartu. Selain itu, apabila guru kurang bisa menguasai kelas secara baik maka akan mudahnya terjadi kegaduh dalam kelas.

Berdasarkan hal di atas, setelah digunakannya media card sort pada pembelajaran hiragana. Peneliti ingin mengetahui tentang persepsi siswa SMAN 3 Bukittinggi terhadap card sort tersebut. Peneliti berasumsi bahwasannya siswa SMAN 3 Bukittinggi memiliki persepsi yang beragam mengenai media card sort jika digunakan sebagai media untuk mempermudah memahami pembelajaran hiragana. Adapun kegunaan diketahuinya persepsi siswa ini yaitu untuk diketahuinya dengan jelas tentang pendapat siswa terhadap media card sort jika digunakan dalam pembelajaran hiragana. Jika banyak dari siswa berpendapat media card sort ini baik maka dapat disimpulkan bahwa media card sort ini efektif untuk mengatasi kesulitan yang dialami oleh pembelajar ketika mengingat dan memahami hiragana. Sebaliknya, jika banyak dari siswa yang berpendapat media card sort ini kurang baik, maka dapat disimpulkan media card sort tidak efektif untuk digunakan dalam pembelajaran hiragana.

\section{METODE PENELITIAN}

Penelitian ini merupakan jenis penelitian kuantitatif. Hal ini dikarenakan data yang dihasilkan berupa angka dan selanjutnya akan dianalisis menggunakan statistik (Sugiyono, 2015). Metode yang dipakai dalam penelitian ini adalah metode deskriptif (Sutedi, 2018), penelitian deskriptif merupakan penelitian yang dilaksanakan untuk menjelaskan, menjabarkan suatu peristiwa yang terjadi pada masa-masa sekarang yang mana untuk menjawab masalah tersebut secara aktual digunakan suatu prosedur yang ilmiah. Melalui rancangan penelitian ini diharapkan penelitian ini dapat memperoleh gambaran secara rinci mengenai persepsi atau pendapat siswa mengenai card sort jika digunakan sebagai media dalam pembelajaran hiragana.

Data penelitian ini berasal dari angket yang sudah dibagikan kepada responden penelitian. Adapun jenis angket/kuisioner yang peneliti pakai adalah jenis angket/kusisioner tertutup. Pada angket/kuisioner tertutup tersebut terdapat beberapa pernyataan dan jawaban yang harus dipilih langsung oleh responden. Pada penelitian ini, skala yang penulis gunakan untuk menjadi acuan pemberian nilai jawaban pada setiap pernyataan yaitu menggunakan skala likert. Digunakannya skala likert ini sebagai acuan pemberian nilai yaitu dikarenakan sesuai dengan pernyataan (Sugiyono, 2015) yang menyatakan bahwa skala likert dapat dijadikan sebagai alat 
ukur sikap, pendapat dan persepsi suatu individu maupun organisasi tentang fenomena sosial.

Pada penelitian ini, peneliti menggunakan angket/kuisioner sebagai alat untuk mengumpulkan data penelitian. Adapun tahapan pengumpulan datanya sebagai berikut: Pertama, menyebarkan angket kepada responden. Angket yang disebarkan disusun dengan kisi-kisi angket yang sudah disesuaikan dengan tujuan penelitian. Selain itu, angket yang akan disebarkan sudah diuji validitas dan reliabilitasnya. Uji validitas dalam penelitian ini ialah validitas isi (content validity). Validitas isi dilakukan untuk mengukur ketepatan suatu tes atau pernyataan dilihat dari isi pernyataan tersebut dengan menganalisis setiap butir pernyataan yang disediakan, sehingga pernyataan yang diberikan tidak menyinpang dari tujuan penelitian (Kurniawan, 2018). Selanjutnya, angket yang akan disebarkan juga di uji reliabilitasnya terlebih dahulu. Hal ini perlu dilakukan untuk untuk menentukan layak atau tidaknya suatu angket diberikan kepada responden. Adapun persamaan untuk menghitung koefisien reliabilitas adalah persamaan Alpha Cronbrach, berikut ini:

$$
r_{11=\frac{k}{k-1}}\left(1-\frac{\sum a b^{2}}{a t^{2}}\right)
$$

Keterangan :

$$
\begin{array}{ll}
r_{11} & =\text { reliabilitas instrumen } \\
\mathrm{k} & =\text { jumlah butir soal } \\
\sum_{\mathrm{ab}^{2}} & =\text { jumlah varian seluruh jumlah soal } \\
\mathrm{at}^{2} & =\text { varians total }
\end{array}
$$

Tabel 1. Interpretasi Nilai $r$

\begin{tabular}{lll}
\hline No & Rentang angka korelasi & Tafsiran \\
\hline $\mathbf{1}$ & $0,00-0,20$ & Sangat rendah \\
$\mathbf{2}$ & $0,21-0,40$ & Rendah \\
$\mathbf{3}$ & $0,41-0,60$ & Sedang \\
$\mathbf{4}$ & $0,61-0,80$ & Kuat \\
$\mathbf{5}$ & $0,81-1,00$ & Sangat kuat \\
\hline
\end{tabular}

(Sutedi dalam Marta dan Yulia, 2019)

Berdasarkan hasil uji coba angket, diketahui data berupa jumlah varian seluruh jumlah soal $\left(\sum \mathrm{ab}^{2}\right)$ sebesar 6,1597 dan varians total $\left(\mathrm{at}^{2}\right)$ sebesar 67,173 sehingga setelah dimasukkan ke dalam rumus pengujian reliabilitas dengan teknik Alpha Cronbach di atas didapatkan nilai reliabilitas 0,96. Hasil ini menunjukkan bahwa instrument berada pada kualifikasi $(0,81-1,00)$, maka instrument penelitian sudah dapat dinyatakan reliabel atau sudah layak digunakan sebagai bahan untuk penelitian.

Kedua, memeriksa kelengkapan angket yang sudah dikembalikan oleh responden setelah diisi. Ketiga, menyiapkan angket yang sudah lengkap untuk diolah. Keempat, mengklasifikasikan data berdasarkan variabel dan jenis responden. Data dikelompokkan berdasarkan skala likert dengan skala penilaian $1-4$ atau dari kriteria sangat tidak setuju, tidak setuju, setuju dan sangat setuju. Konversi yang dilakukan terhadap data mengacu pada rumus konversi (Sugiyono, 2015). Kelima, 
mencari jumlah skor setiap butir pernyataan pada masing-masing jawaban responden. Keenam,mengelompokkan angket berdasarkan indikator angket. Ketujuh, mencari skor total daripara responden. Kedelapan, mengolah data angket berupa angka. Kesembilan, mentabulasikan data hasil angket siswa.

Selanjutnya yaitu teknik analisis data angket yang sudah dikumpulkan sebelumnya. Teknik analisis yang digunakan dalam penelitian ini ialah teknik analisis statistik deskriptif. Analisis statistik deskriptif adalah sebuah teknik statistik yang digunakan untuk menganalisa suatu data dengan cara menjelaskan atau mengambarkan data yang telah terkumpul tanpa menambahkan suatu hal dan juga bukan untuk menarik kesimpulan yang berlaku umum atau generalisasi. Penganalisisan data yang dilakukan dengan langkah-langkah berikut: Pertama, menghitung jumlah skor tertinggi dan terendah untuk item penilaian. Kedua, mencari jumlah skor persentase minimal dan skor persentase maksimal untuk menentukan kategori interval. Ketiga, mencari interval dan interpretasi persen untuk mengetahui penilaian dengan interval skor persen. Adapun interval penilaian skor persen dapat dilihat pada tabel berikut ini:

Tabel 2. Interval Penilaian

\begin{tabular}{ll}
\hline Angka & Penafsiran \\
\hline $25 \%-50 \%$ & Kurang baik \\
$51 \%-75 \%$ & Cukup baik \\
$76 \%-100 \%$ & Baik \\
\hline
\end{tabular}

Keempat, yaitu menentukan kategori persepsi siswa dengan cara menghitung persentase jawaban dari tiap butir pernyataan dan indikator. Kelima, menghitung nilai sub indikator dari rata-rata nilai item pernyataan dan menghitung nilai indikator dari rata-rata nilai sub indikator. Keenam, melakukan analisis data yang telah dihitung dengan berpedoman terhadap interval penilaian. Ketujuh, interpretasi hasil data dan pembahasan. Kedelapan, membuat kesimpulan penelitian.

\section{HASIL DAN PEMBAHASAN}

Temuan Penelitian

Adapun hasil temuan yang didapatkan setelah melakukan perhitungan pada setiap sub indikator dan pernyataan yang terdapat pada indikator angket dan analisis terhadap hasil angket yang telah disebarkan sebelumnya kepada siswa kelas $\mathrm{X}$ BAHASA SMAN 3 Bukittinggi yang berjumlah 35 orang. Peneliti dapat mengetahui persepsi siswa terhadap card sort sebagai media pembelajaran hiragana. Penjelasannya dapat dilihat pada tabel di bawah ini. 
Tabel 3 Nilai Rata-rata Skor Indikator

\begin{tabular}{|c|c|c|c|c|c|}
\hline \multirow[t]{2}{*}{ Variabel } & \multirow{2}{*}{$\begin{array}{l}\text { Indikator } \\
\text { Persepsi }\end{array}$} & \multicolumn{2}{|c|}{ Sub Indikator } & \multirow{2}{*}{$\begin{array}{c}\text { Skor } \\
\text { Persentase } \\
\text { Indikator }\end{array}$} & \multirow{2}{*}{$\begin{array}{l}\text { Kategori } \\
\text { Persepsi }\end{array}$} \\
\hline & & Skor & $\begin{array}{c}\text { Skor } \\
\text { Persentas } \\
\text { e } \\
\end{array}$ & & \\
\hline \multirow{10}{*}{$\begin{array}{l}\text { Persepsi siswa } \\
\text { terhadap media } \\
\text { card sort } \\
\text { sebagai media } \\
\text { pembelajaran } \\
\text { hiragana }\end{array}$} & \multirow{5}{*}{$\begin{array}{l}\text { Penyerapan } \\
\text { terhadap } \\
\text { rangsangan atau } \\
\text { objek }\end{array}$} & 119 & $85 \%$ & \multirow[t]{5}{*}{$83,14 \%$} & \multirow[t]{5}{*}{ Baik } \\
\hline & & 118 & $84,29 \%$ & & \\
\hline & & 118 & $84,29 \%$ & & \\
\hline & & 114 & $81,43 \%$ & & \\
\hline & & 113 & $80,71 \%$ & & \\
\hline & \multirow{3}{*}{$\begin{array}{l}\text { pengertian atau } \\
\text { pemahaman }\end{array}$} & 118,33 & $84,52 \%$ & \multirow[t]{3}{*}{$84,48 \%$} & \multirow[t]{3}{*}{ Baik } \\
\hline & & 117 & $83,57 \%$ & & \\
\hline & & 119,5 & $85,36 \%$ & & \\
\hline & \multirow{2}{*}{$\begin{array}{l}\text { penilaian atau } \\
\text { evaluasi }\end{array}$} & 119,67 & $85,48 \%$ & \multirow{2}{*}{$82,02 \%$} & \multirow[t]{2}{*}{ Baik } \\
\hline & & 110 & $78,57 \%$ & & \\
\hline \multicolumn{2}{|c|}{ Rata-rata } & 116,65 & $83,32 \%$ & $83,22 \%$ & Baik \\
\hline
\end{tabular}

Dari tabel di atas peneliti mengetahui rata-rata skor persentase indikator persepsi siswa terhadap media card sort sebagai media pembelajaran hiragana, yaitu $83,22 \%$ yang mana tergolong pada kategori persepsi "baik". Selain itu, dari tabel di atas juga tidak terdapat hasil yang menunjukkan bahwasannya siswa memiliki persepsi kurang baik terhadap penggunaan media card sort sebagai media pembelajaran untuk mempermudah dalam mempelajari hiragana. Oleh karena itu, dapat disimpulkan bahwa siswa berpendapat baik terhadap media card sort jika digunakan sebagai media pada pembelajaran hiragana.

Pembahasan

Untuk memperjelas tabel di atas, adapun skor persentase setiap indikator dibuat dalam bentuk grafik adalah sebagai berikut:

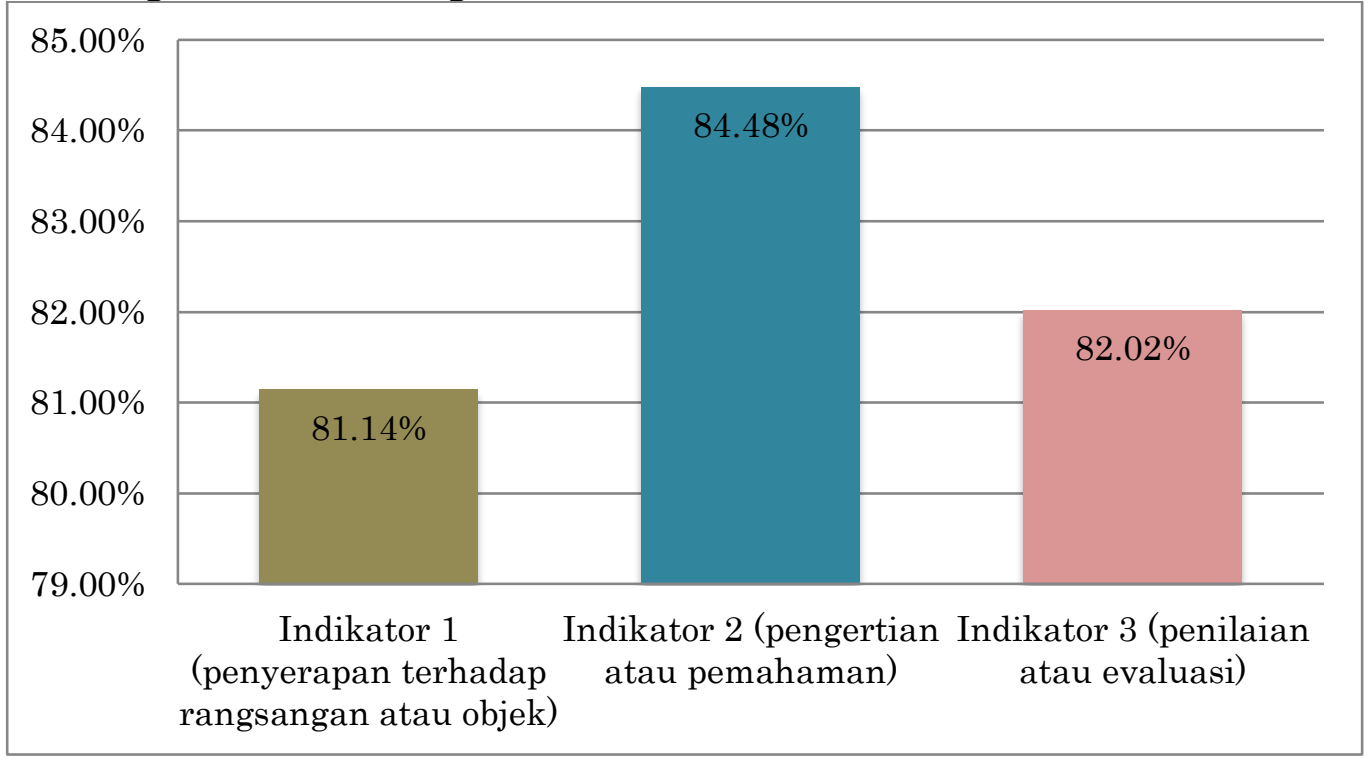

Grafik 1. Skor persentase per indikator 
Dari grafik di atas, adapun skor persentase indikator tertinggi yaitu terdapat pada indikator 2 yaitu "Pengertian atau pemahaman" yang memiliki skor persentase terbanyak yaitu $84,48 \%$. Dari skor persentase tersebut dapat disimpulkan bahwa pengertian atau pemahaman siswa terhadap media card sort jika digunakan dalam pembelajaran hiragana sudah termasuk pada kategori baik. Hal ini berarti bahwa siswa berpendapat setelah menggunakan media card sort siswa tertarik untuk belajar, dapat mengikuti proses pembelajaran secara baik, dan motivasi untuk belajar hiragana meningkat. Selain itu, dalam penyampaian materi guru media card sort ini membantu guru untuk memperjelas penyampaian materi hiragana kepada siswa dan selama penggunaan media card sort ini hubungan siswa dan guru menjadi interaktif.

Selanjutnya, indikator dengan skor tertinggi yaitu indikator 1 "penyerapan terhadap rangsangan atau objek" dengan skor persentase 83,14\%. Berdasarkan skor persentase tersebut diketahui bahwa penyerapan siswa terhadap rangsangan atau objek yaitu media card sort termasuk pada kategori persepsi baik. Rangsangan yang diserap oleh siswa selama belajar menggunakan media card sort adalah bahwa selama menggunakan media card sort siswa berpendapat guru sudah menguasai media sehingga tidak menimbulkan kebingungan pada siswa. Selain itu, materi yang disampaikan dengan media card sort sudah sesuai dengan materi hiragana, media card sort yang digunakan sesuai dengan kemampuan, situasi dan kondisi siswa. Metode belajar yang digunakan juga tepat sehingga meningkatkan kegairahan siswa dalam belajar dan menurut pendapat siswa media media card sort juga efisien dan dapat menarik perhatian siswa selama proses pembelajaran.

Berikutnya, indikator 3 "penilaian atau evaluasi" yang memiliki skor persentase $82,02 \%$ yang juga termasuk ke dalam kategori persepsi baik. Dari hasil jawaban siswa dapat dilihat bahwa siswa berpendapat bahwa penilaian siswa terhadap media card sort jika digunakan sebagai media pembelajaran "baik" dan sesuai dengan tujuan pembelajaran hiragana. Selain itu, siswa juga menilai bahwa penggunaan media card sort dalam pembelajaran hiragana memberikan pengaruh positif yaitu dengan meningkatkan hasil belajar siswa. Oleh karena itu, dapat dinyatakan bahwa siswa memiliki persepsiatau kesan dan penilaian yang baik terhadap media card sort digunakan sebagai media dalam pembelajaran hiragana.

Dari tabel dan penjelasan di atas peneliti mengetahui rata-rata skor persentase persepsi siswa terhadap media card sort sebagai media pembelajaran hiragana, yaitu $83,22 \%$ yang mana tergolong pada kategori persepsi "Baik". Selain itu, dari tabel di atas juga tidak terdapat hasil yang menunjukkan bahwasannya siswa memiliki persepsi kurang baik terhadap penggunaan media card sort apabila digunakan sebagai media pembelajaran untuk mempermudah dalam mempelajari hiragana.

Senada dengan hasil penelitian yang relavan, yaitu penelitian Nikmah (2017) yang berjudul "Persepsi Siswa Terhadap Media Card Sort Sebagai Media Pembelajaran Kosakata Bahasa Jepang". Adapun hasil dari penelitiannya terdapat dua persepsi mengenai media card sort yaitu persepsi baik dan kurang baik. Adapun persepsi baik terhadap media card sort ini paling banyak ditujukan pada indikator fungsi media yaitu sebanyak $57,71 \%$. Mayoritas siswa berpendapat bahwa dengan media card sort siswa lebih tertarik untuk fokus terhadap pelajaran. Selain meningkatkan fokus siswa terhadap pelajaran dengan media card sort juga menjadikan proses pembelajaran menyenangkan, mempermudah siswa memahami 
dan mengingat informasi dan dapat mengurangi peluang siswa menjadi pasif selama proses pembelajaran.

Selanjutnya, persepsi baik siswa juga banyak ditujukan untuk indikator kegunaan media yaitu sebanyak 49,67\%. Siswa berpersepsi bahwa dengan menggunakan media card sort penyampaian materi juga lebih jelas dan karena pelaksanaannya secara berkelompok siswa dapat mendengarkan dan berdiskusi dengan temannya untuk menyamakan pendapat. Berikutnya, persepsi baik juga banyak ditujukan oleh siswa pada indikator manfaat dan tujuan media card sort. Sebanyak 44,5\% siswa berpersepsi jika dengan menggunakan media card sort mempermudah mereka dalam menghafal dan mengingat materi pembelajaran. Selanjurnya pada indikator komponen-komponen media card sort yaitu sebanyak $3,8 \%$. Siswa mengakui bahwa dengan menggunakan media card sort interaksi sesama siswa dapat terjalin secara baik.

Selain itu, pada indikator prinsip-prinsip media card sort sebanyak $4,4 \%$ siswa berpendapat lebih mudah menyelesaikan tugas dengan media card sort. Indikator terakhir yang memiliki persepsi baik dari siswa yaitu indikator keunggulan media card sort. Sebanyak 3,6\% menyatakan dengan media card sort proses pembelajaran menjadi lebih menyenangkan, hal ini dikarenakan proses belajar yang tidak monoton dan disertai dengan permainan.

Selain memiliki persepsi baik mengenai media card sort, dalam hasil penelitian Nikmah (2017) juga terdapat persepsi kurang baik mengenai media card sort yaitu terdapat $12,33 \%$ siswa mengaku bahwa pembelajaran dengan menggunakan media card sort kurang menarik perhatian dan kurang meningkatakan minat mereka untuk belajar, sehingga menjadikan timbulnya rasa malas untuk memperhatikan pembelajaran.

Pada penelitian Nikmah (2017), persepsi baik terhadap media card sort ini paling banyak ditujukan pada indikator fungsi media yaitu sebanyak 57,71\%. Berbeda dengan hasil penelitian ini yaitu persepsi atau pendapat baik terhadap media card sort paling banyak ditujukan pada indikator "pengertian dan pemahaman" dengan skor persentase sebanyak 84,48\%.

Adapun kesimpulan dari penelitian Nikmah (2017) dan penelitian ini adalah sama-sama memiliki hasil perhitungan rata-rata persepsi siswa terhadap media card sort sebagai media pembelajaran tergolong pada kategori baik. Diketahui hasil perhitungan rata-rata dari penelitian Nikmah (2017) ini tergolong tinggi yaitu sebesar 80,74\%. Adapun dalam penelitian ini, hasil perhitungan rata-rata persepsi siswa terhadap card sort sebagai media pembelajaran hiragana yaitu $83,22 \%$ yang juga termasuk dalam kategori persepsi baik.

\section{KESIMPULAN}

Dari hasil analisis data penelitian di atas dapat ditarik kesimpulan bahwa penggunaan media card sort untuk pembelajaran hiragana sudah berjalan secara secara baik dan dapat diterima oleh siswa. Hal ini berdampak terhadap hasil perhitungan persepsi siswa terhadap penggunaan media card sort untuk pembelajaran hiragana. Persepsi siswa mengenai media card sort secara keseluruhan tergolong pada kategori "baik". Hal ini beracuan pada rata-rata skor persentase dari keseluruhan indikator yang tergolong tinggi yaitu $83,22 \%$. Dari nilai rata-rata skor 
persentase tersebut dapat disimpulkan bahwa indikator penyerapan terhadap rangasangan atau media card sort oleh siswa, indikator pengertian atau pemahaman siswa setelah menggunakan media card sort untuk pemebelajaran hiragana dan indikator penilaian atau evaluasi siswa terhadap media card sort juga sudah termasuk pada kategori "baik".

\section{REFERENSI}

Haq, M. (2019). Hiragana Goi Karuta sebagai Media Pembelajaran Kosakata Dasar Bahasa Jepang.

Kurniawan, Asep. 2018. Metodologi Penelitian Pendidikan. Bandung; PT Remaja Rosdakarya

Marta, A., dan Nova, Yulia. 2019. Pengaruh Media Kartu Kuartet terhadap Penguasaan Hiragana Siswa Kelas X SMAN 6 Padang. Omiyage : Jurnal Bahasa Dan Pembelajaran Bahasa Jepang, 3(2), 2-11.

Nikmah, F. 2017. Persepsi Siswa Terhadap Media Card Sort Sebagai Media Pembelajaran Kosakata Bahasa Jepang. Skripsi. Fakultas Bahasa dan Seni. Universitas Negeri Semarang.

Renariah. 2002. Bahasa Jepang dan Karakteristiknya. Jurnal Sastra Jepang Fakultas Sastra Universitas Kristen Maranatha. 1(2), 1--16.

Sadiman, Arief S, dkk. 2014. Media Pendidikan. Jakarta;PT Raja Grafindo Persada.

Sugiyono. 2015. Metode Penelitian dan Pengembagan (Research and Development/R\&D). Bandung: Alfabeta.

Sutedi, Dedi. 2011. Dasar-dasar Linguistik Bahasa Jepang. Bandung: Humaniora. 2018. Penelitian Pendidikan Bahasa Jepang. Bandung: UPI Press.

Welhelmina, M. 2017. Implementasi Penerapan Alphabox Strategy dalam Meningkatkan Kosakata Siswa Kelas XII pada Materi Ajar Hoby Und Freizeitbeschafigung di SMA Negeri 1 Saparua. Jurnal Tahuri:Jurnal Ilmiah Pendidikan Bahasa, 14(2), 22-30.

Yani, Damai. 2017. "Penggunaan Aplikasi Kanji Senpai pada Android untuk Belajar Kanji Secara Mandiri." Universitas Negeri Padang Repository. 